\title{
Behavior of Diffusion, Permeation and Sorption of Flavor Compounds in Vapor Phase with Polyethylene Film
}

\author{
Mitsuya Shimoda*, Toshirou Matsui* and Yutaka Osajima* \\ *Department of Food Science and Technology, Faculty of Agriculture, \\ Kyusyu University, 6- 10-1, Hakozaki, Higashi-ku, Fukuoka 812
}

\begin{abstract}
A new method for measurement of diffusion, permeation and sorption coefficients of volatile compounds in polyethylene (PE) film was established. The activation energies for the diffusion in middle density PE (MDPE) of $n$-octane, ethyl caproate, $n$-octanal and $n$ octanol were 14.6, 10.5, 15.0 and $19.2 \mathrm{kcal} / \mathrm{mol}$, respectively. Although the molecular volumes of penetrants were the almost same value, it was indicated that the hole volumes in the $\mathrm{PE}$ required for the penetrants to diffuse or jump were quite different. The enthalpy changes in sorption from vapor phase were $-9.1,-8.2,-2.7$ and $-10.7 \mathrm{kcal} / \mathrm{mol}$, respectively, that is, all the sorption were exothermic process. The decrease in enthalpy was associated with the increase in boiling points of penetrants and the increase in affinities for PE.
\end{abstract}

The permeation of organic vapors in a plastic film has been studied from the viewpoint of polymer physics ${ }^{1 \sim 4}$. However, food scientists were not much interested in these studies because the experimental objects are quite different. On food flavors, IsHITANI ${ }^{5)}$ measured the decreasing rate of volatile vapor filled in a pouch, but could not distinguish between the permeation and the sorption in regard to the decrease of volatile compounds. BLAKESLEY et $a{ }^{6}{ }^{6}$ reported the method for estimating the coefficients of diffusion, permeation and solubility of volatile compounds in a plastic film, but their method was time- consuming for even quite small penetrant molecules. The dynamic approach to the measurement of diffusion, permeation and solubility coefficients by PASTERnAK et $a l .{ }^{7)}$ was inadaptable for the measurement under a low vapor pressure because of the monitoring by thermal conductivity detector (TCD).

In this paper, we report the method for measurement of diffusion, permeation and solubility coefficients under a low vapor pressure by use of gas chromatograph equipped with a flame ionization detector (FID). Fur- thermore, the effects of boiling points and affinities for PE on the diffusion and sorption of volatile compounds were discussed.

\section{Materials and Methods}

\section{Materials}

Middle density polyethylene (MDPE) films used here were obtained from Showa Denko Co., Ltd. The films were fabricated by an inflation method and the thickness of films was measured accurately to the nearest $\mu \mathrm{m}$ by thick meter (Ozaki MFG. Co., Ltd). The density of MDPE films was $0.9367 \mathrm{~g} / \mathrm{cm}^{3}$.

\section{Methods}

\section{1) Apparatus and procedure}

The assembled permeation cell and components are depicted in Fig. 1. The permeation cell was constructed in the oven of gas chromatograph (Shimadzu GC- 8A) equipped with thermostat. A film was clamped between two flat surfaces of the glass permeation cells. The exposed circular area of the film was 3.8 $\mathrm{cm}^{2}$ and the volume of each cell compartment was $3 \mathrm{~cm}^{3}$ for penetrants with a permeation coefficient less than $10^{-4} \mu \mathrm{g} \cdot \mathrm{sec}^{-1} \cdot \mathrm{cm}^{-1}$. $\mathrm{mmHg}^{-1}$, and $0.78 \mathrm{~cm}^{2}$ and $0.8 \mathrm{~cm}^{3}$ for penet- 


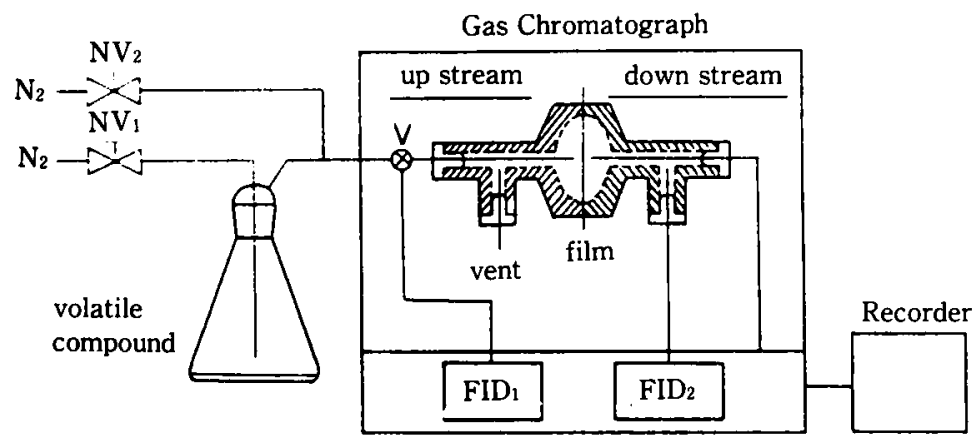

Fig. 1 Diagram of the measuring system for permeation experiment $\mathrm{NV}_{1}, \mathrm{NV}_{2}$; flow control valve, $\mathrm{V}$; three-way valve, $\mathrm{FID}_{1}$, $\mathrm{FID}_{2}$; flame ionization detector.

rants having a permeation coefficient more than $10^{-4} \mu \mathrm{g} \cdot \mathrm{sec}^{-1} \cdot \mathrm{cm}^{-1} \cdot \mathrm{mmHg}^{-1}$.

First, the upstream, stream of nitrogen gas containing volatile compound (penetrant) in a constant vapor pressure, was directly introduced into FID 1 . The flow rate $(I o ; \mu \mathrm{g} / \mathrm{sec})$ of volatile compounds was determined on the basis of the height of recorder response $(H$; $\mathrm{mv})$ and the flow rate of the upstream $(V 1 ; l)$ sec) was measured by a flow meter in order to calculate the vapor pressure of volatile compounds in the upstream (Pi1; mmHg). Then, the downstream (carrier gas in gas chromatography), stream of nitrogen gas containing the volatile compounds permeated through the film, was monitored by FID 2, and when the straight base line was established, the upstream was introduced into the cell by turning the valve (V). In an actual run, the flow rate of the upstream ranged from 30 to $60 \mathrm{ml} / \mathrm{min}$, and $30 \mathrm{ml} / \mathrm{min}$ for the downstream. Both conpartments are at atmospheric pressure, thus no film support is required and leakage problems are minimal.

2) Calculation of diff usion, permeation and sorption coefficients

The differential permeation curve obtained by the present method is shown in Fig. 2. The mathematical formulation for deriving the diffusion coefficient from the transient permeation rate has been developed by PASTERNAK et $a l^{7}$. The diff usion coefficient $\left(D: \mathrm{cm}^{2} \cdot \mathrm{sec}^{-1}\right)$

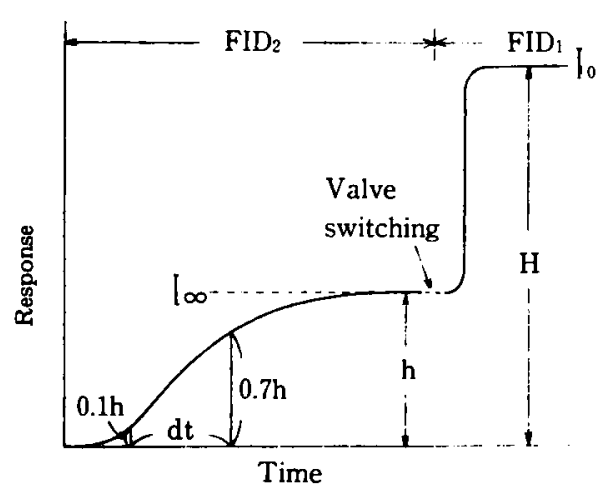

Fig. 2 Typical differential permeation curve of volatile compound obtained by FID.

was calculated from

$$
D=0.505 l^{2} / 4 d t
$$

where $l$ is the thickness of film $(\mathrm{cm}), d t$ is the time (sec) taken from $0.1 \mathrm{~h}$ to $0.7 \mathrm{~h}$ as shown in Fig. 2. It should be noticed that equation (1) is adaptable under the condition of $P i 1$ $\gg P i 2=0$, where $P i 2$ is the vapor pressure $(\mathrm{mmHg})$ of the downstream. The permeation coefficient $\left(P: \mu \mathrm{g} \cdot \mathrm{sec}^{-1} \cdot \mathrm{cm}^{-1} \cdot \mathrm{mmHg}^{-1}\right)$ was calculated from

$$
P=I \cdot l / A \cdot(P i 1-P i 2)=I \cdot l / A \cdot P i 1 \text { (2) }
$$

where $I$ is the flow rate $\left(\mu \mathrm{g} . \sec ^{-1}\right)$ of volatile component in the downstream under a steady state, $A$ is the exposed area of the film $\left(\mathrm{cm}^{2}\right)$. $P i 1$ and $P i 2$ are calculated from

$$
P i 1=l o \cdot R \cdot T /(M w \cdot V 1) \times 760 \times 10^{6}
$$


$P i 2=I \cdot R \cdot T /(M w \cdot V 2) \times 760 \times 10^{6}$ where $R$ is a gas constant $\left(l \cdot \mathrm{atm} \cdot \mathrm{deg}^{-1}\right), T$ is an absolute temperature $\left({ }^{\circ} \mathrm{K}\right), V 2$ is the flow rate of the downstream $(l / \mathrm{sec}), M w$ is the molecular weight $(\mathrm{g})$ of volatile component. When $k$ represents the magnitude of FID response (mv . sec) for $1 \mu \mathrm{g}$ of the volatile component, $I o=H / k, I=h / k$. From dissolution- diffusion theory ${ }^{8)}$, a solubility coefficient ( $S: \mu \mathrm{g} \cdot \mathrm{cm}^{-3} / \mathrm{mmHg}$ ) is defind as follows :

$$
S=P / D
$$

\section{Results and Discussion}

The experiment of permeation should be carried out under the vapor pressure as low as possible because the volatile compounds exist in the extremely low pressure in the headspace gas of foods. In this experiment, the vapor pressure in the upsteam was controlled at a given pressure from 0.1 to $0.5 \mathrm{mmHg}$, while the concentration of volatile compounds on the exposed surface of PE film, the product of $S$ and $P i l$ ranged from 0.2 to $0.7 \%(\mathrm{w} / \mathrm{w})$. In such circumstance, the diffusion coefficient estimated is considered to be practically equal to its intrinsic diffusion coefficient which was desingated by HARTLEY and CRANK ${ }^{9 \text { ? }}$.

The experiments were carried out at $25^{\circ} \mathrm{C}$ using films of various thickness fabricated from the same PE material. Fig. 3 shows the plots of diffusion, permeation and sorption coefficients of $n$-octanal against the film thickness. The diffusion, permeation and sorption coefficients decreased slightly with the increase of thickness. It is thought that this is responsible for the difference in the fabrication process of films because the differences in drawing ratio and cooling rate in the process cause the changes in orientation, shape and size of crystallites.

Fig. 4 shows the Arrhenius plots for diffusion, permeation and sorption of $n$-octanol in MDPE. Each plot gave a straight line from 1 ${ }^{\circ} \mathrm{C}$ to $45^{\circ} \mathrm{C}$. The diffusion and permeation coefficients significantly increased with the increase in temperature while the solubility coefficient decseased. On the other hand, the studies $^{10)}$ on gas permeation have revealed that

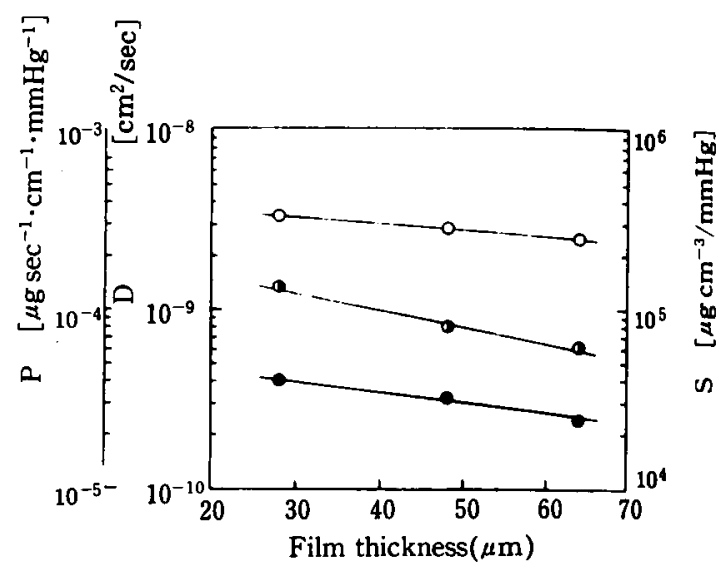

Fig. 3 Diffusion, permeation and solubility coefficients measured with PE films different in thickness

0 ; diffusion coefficient,

a ; permeation coefficient.

- ; solubility coefficient.

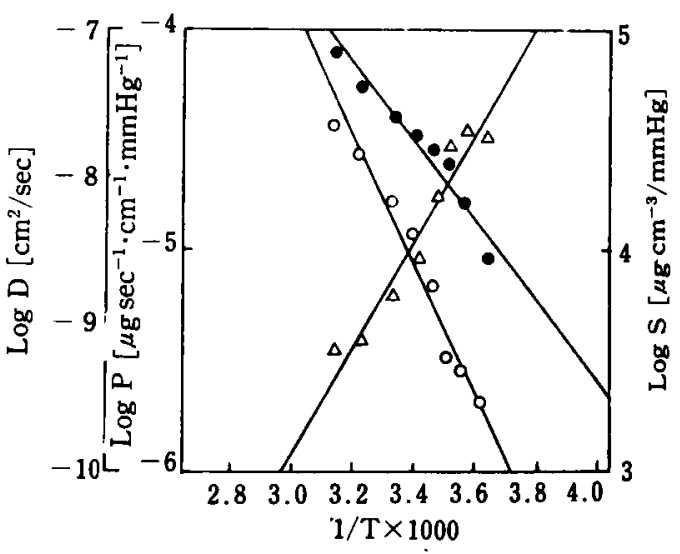

Fig. 4 ArRhenius plots of diffusion, permeation and sorption coefficients

Penetrant ; $n$-octanol, polymer; MDPE

-O- ; diffusion coefficient

$-\bullet-$; permeation coefficient

$-\Delta-$; sorption coefficient

the diffusion and permeation increased with temperature but little influence was observed on the sorption. It is apparent from the comparison of gaseous system with volatile one that the increase in sorption of volatile compounds at low temperature results from 
Table 1 Activation energies for diffusion and permeation and enthalpy change in sorption, and boiling points and molecular volumds of penetrants

\begin{tabular}{lcccc}
\hline \hline & Octane & $\begin{array}{l}\text { Ethyl } \\
\text { caproate }\end{array}$ & Octanal & Octanol \\
\hline Boiling point $\left({ }^{\circ} \mathrm{C}\right)$ & 126 & 167 & 163 & 195 \\
Molecular volume $\left(\AA^{3}\right)$ & 149 & 160 & 150 & 156 \\
\hline$E_{\mathrm{D}}(\mathrm{kcal} / \mathrm{mol})$ & 14.6 & 10.5 & 15.0 & 19.2 \\
$\mathrm{E}_{\mathrm{P}}(\mathrm{kcal} / \mathrm{mol})$ & 5.5 & 2.3 & 12.3 & 8.5 \\
$\Delta_{\mathrm{H}}(\mathrm{kcal} / \mathrm{mol})$ & -9.1 & -8.2 & -2.7 & -10.7 \\
\hline
\end{tabular}

$E_{D}$; activation energy for diffusion, $E_{P}$; activation energy for permeation,

$\Delta_{\mathrm{H}}$; enthalpy change in sorption.

their high boiling points and from their high affinities for PE molecules. Table 1 lists the boiling points, molecular volumes ${ }^{11}$, activation energies for diffusion, permeation and the enthalpy changes in sorption with respect to $n-$ octane, ethyl $n$-caproate, $n$-octanal and $n$ octanol, respectively. The relationships between the activation energy for diffusion and the penetrant molecule have been reported on gas molecules. In the case of poly (ethyl methacryrate), a log-log plot of the activation energy for diffusion against the viscosity molecular diameter of penetrant gave a straight line of slope $1.6^{12)}$. The activation energy in rubber was found to be proportional to the penetrant diameter, wheseas with poly (vinyl acetate) and poly (ethylene terephthalate) the activation energy was found to be proportional to the penetrant diameter squar$\mathrm{ed}^{13)}$. The present data indicate that the high activation energy for the alcohol results from the addition of a hydroxy group to the carbon chain and that the bending of carbon chain at an ester binding makes the activation energy low. Although their molecular volumes were the almost same values, it was thought that the hole volumes ${ }^{4) 5}$ in the $\mathrm{PE}$ required for the penetrants to diffuse or jump were quite different. This was a definitive difference between inorganic gas molecules and organic volatiles. The enthalpy changes in sorption were all negative, that is, the sorptions in polyethylene of organic vapors were exothermic process. It is thought that the negative large value for the alcohol comes from its high boiling point, whereas that the negative large value for the hydrocarbon comes from its high affinity for PE molecule. The boiling point of the ester is about the same temperature as that of the aldehyde but the enthalpy change for the ester was larger than that for the aldehyde because of its high affinity for PE molecules. Further work is required to clear the relation between the hole volume required by penetrant and the affinity for PE.

In conclusion, it has been revealed that the boiling point and affinity for PE molecules significantly affected the sorption of volatile compounds in vapor phase.

\section{References}

1) Kulkarni, S.S. and Stern, S.A.: J. Polym. Sci. Polym. Phys. Ed., 21, 441 (1883).

2) Choy, C.L., Leung, W.P. and Ma, T.L. : $J$. Polym. Sci. Polym. Phys. Ed., 22, 707 (1984).

3) Lzydorczyk, J. and Salwinskt, J.: J. Appl. Polym. Sci., 29, 3663 (1984).

4) Hg, H.C., Leung, W.P. and Choy, C.L. : $J$. Polym. Sci. Polym. Phys. Ed., 23, 973 (1985).

5) IsHitaNI, T.: Nippon Shokuhin Kogyo Gakkaishi, 28, 221 (1981).

6) Blakesley, G.N.: J. Food Technol., 9, 285 (1974).

7) Pasternak, P.A., Schimschemer, J.F. and Heller, J.: J. Polym. Sci. Polym. Phys. Ed., 8, 467 (1970).

8) Nippon Kagaku Kai ed. "Kagakusousetu, No. 45, Kinousei Yuukihakumaku" (Gakkai Syuppan Sentā), p.20 28 (1984) .

9) Hartley, G.S. and Crank, J.: Trans. 
Faraday Soc., 45, 801 (1949).

10) Macdonald, R.W. and Huang, R.Y.M. : $J$. Appl. Polym. Sci., 26, 2239 (1981).

11) Slonimskil, G.L., Askadskil, A.A. and Kitaigorodskir, A.1. : Polymer Sci. U.S.S. $R ., 12$ (3), 556 (1970).

12) Stannett, $V$. and Williams, J.L.: $J$. Polym. Sci., Part C (10), 45 (1965)

13) Michaels, A.S., Vieth, W.R. and Barrie, J.A. : J. Appl. Plys., 34, 13 (1963).

14) Kusumoto, S., Sano, S. and Motozato, Y.: Polymer., 17, 448 (1976).

15) Bullock, A.T., Cameron, G.G. and Miles, I.S. : Polymer., 23, 1536 (1982).

(Received Jul. 15, 1986)
気相中の香気成分のボリエチレンフィルムに

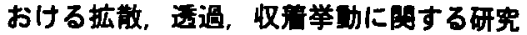

\section{下田満哉* ・松井利郎* ・筬島 業" \\ "九州大学農学部 \\ （广812，福岡市東区箱崎六丁目10-1）}

香気成分のポリエチレンフィルムにおける㹡散，透過， 溶解度係数の測定法を新たに設定した。 中密度ポリエチ レン中における $n$-オクタン，エチルカプロエート，nオクタナール, nーオクタノールの㧧散の活性化エネル ギーは，それぞれ 14.6,10.5，15.0，19.2 kcal/mole であった.これらのペネトラントの分子容積はほぼ同じ であったが、ペネトラントが PE 中で拡散、すなわち ジャンプするのに必要な微穴の签積はかなり違うことか 示唆された，一方，これらの成分の気相からの収着にお けるエンタルピー変化は，それぞれー9.1，-8.2，-2.7, - $10.7 \mathrm{kcal} / \mathrm{mole}$ であり, すべて発熱過程であった. エンタルピーの減少は, ペネトラントの沸点が高いはど, そして PE に対する親和性が高いほど著しかった。 